Revista Pax Domini é licenciada sob uma Licença Creative Commons.

\title{
PANORAMA HISTÓRICO DO DOGMA TRINITÁRIO DO CONCÍLIO DE NICÉIA ATÉ O DE CONSTANTINOPLA
}

Reginaldo Bello Pereira*

Daniel Barros de Lima*

\begin{abstract}
Resumo
Este artigo apresenta um panorama histórico cujo objetivo é o de fazer uma análise sobre a formulação do dogma Trinitário abordando do concílio de Niceia até o de Constantinopla. A metodologia empregada neste estudo foi a histórica bibliográfica, utilizando livros de autores renomados tais como GONZÁLEZ, Justo L., KELLY, J. N. D, PELIKAN, Jaroslov., WALKER, Wiliston., OLSON, Roger. O resultado de toda essa análise histórica é o de que o concílio de Nicéa foi realizado a partir de uma ordem de Constantino afim de propor um fim às conturbações teológicas acerca da divindade de Cristo promovidas pelo arianismo. E, anos depois é realizado o concílio de Constantinopla cuja finalidade foi a de ressaltar a divindade do Filho, acrescentar a sua humanidade e acrescentando também a divindade do Espírito Santo. A importância de se estudar os dogmas e as doutrinas do cristianismo é valorável por conceder o poder de não transformar o cristianismo numa religião mitológica servindo apenas como uma solução terapêutica. O importante não é só conhecer as doutrinas, mas também pensamentos divergentes à doutrina Trinitária. Pois a formulação do dogma Trinitário só foi possível a partir dos pensamentos arianistas.
\end{abstract}

Palavras-chave: Arianismo, Costantino, dogma, homoousios.

\begin{abstract}
This article presents a historical overview whose goal is to make an analysis on the formulation of the Trinitarian dogma addressing the council of Nicaea until Constantinople. The methodology used in this study was the historical literature, using books from renowned authors such as GONZÁLEZ, Justo L., KELLY, JN D, PELIKAN, Jaroslov., WALKER, Wiliston., OLSON, Roger. The result of all this historical analysis is that the Council of Nicaea was held from an order of Constantine in order to propose an end to theological upheavals of the divinity of Christ promoted by Arianism. And years after the Council of Constantinople is held whose purpose was to emphasize the divinity of the Son, add your humanity and also adding the divinity of the Holy Spirit. The importance of studying the dogmas and doctrines of Christianity is valoravel owing to the power not to turn Christianity into a mythological religion serving only as a therapeutic solution. What is important is not just knowing doctrines, but also divergent thoughts on Trinitarian doctrine. For the formulation of the Trinitarian dogma was only possible from the Arians thoughts.
\end{abstract}

Key-words: Arianismo, Costantino, dogma, homoousios.

\footnotetext{
* Possui graduação em Ciências Teológicas pela Faculdade Boas Novas (2014) e Especialização em Ensino Religioso pela Faculdade Boas Novas (2015).). E-mail: bellodj13@gmail.com

** Mestre em História Social (2016). Possui licenciatura Plena em História (2011) e Especialização em Metodologia do Ensino Superior (2010) e bacharelado em Ciências Teológicas (2008). Doutorando em Teologia (DINTER) pelo PPG-EST São Leopoldo/RS (2016). Docente da Faculdade Boas Novas. E-mail: daniel.barros@fbnovas.edu.br
}

Revista Pax Domini | Faculdade Boas Novas | v. 2 | p. 122 - 145 | mar. 2017 


\section{INTRODUÇÃO}

A Doutrina da trindade ainda hoje é um assunto que possui apurado grau de complexidade em sua compreensão. O seu desenvolvimento foi marcado por inúmeras discussões que tinham por finalidade esclarecer a apresentação de um único Deus em três pessoas: Pai, Filho e Espírito. A consequência disto levou a formação de vários concílios. Os concílios destacados neste estudo são os Concílios de: Nicéia e o de Constantinopla.

O presente estudo vem esclarecer as principais diferenças entre os concílios de Niceia e o de Constantinopla, apresentando um panorama histórico e as soluções apresentadas em cada um deles. A importância deste, para a atualidade, deve-se ao fato de os concílios de Nicéia e Constantinopla ainda hoje serem tidos como ecumênicos por grande parte das Igrejas, e também merecendo destaque pela autoridade e importância histórica que possuem.

Para a realização deste trabalho utilizou-se o método histórico bibliográfico. E, de acordo com BASTOS (apud Gil, 1995), a pesquisa bibliográfica define-se basicamente por uma coleta de material disponível e já existente, o qual pode ser selecionado a partir de livros, de revistas, de periódicos especializados e de documentos diversos. ${ }^{1}$

Por assim ser, buscou-se utilizar referências sobre: a origem e desenvolvimento das doutrinas da fé cristã, história do cristianismo, introdução à Trindade, Patrística, história dos concílios ecumênicos, a história da teologia cristã e teologia sistemática. Sendo tais assuntos consultados nas obras de autores renomados que dentre os quais se destacam GONZÁLEZ, Justo L., KELLY, J. N. D, PELIKAN, Jaroslov., WALKER, Wiliston., OLSON, Roger., dentre outros. Afim de sumarizar as informações encontradas nessas literaturas, foram feitos diversos fichamentos e análise críticas. Para construção textual do projeto, escolheu-se fazer a partição histórica através dos objetivos específicos deste estudo.

A partir de todos os dados coletados durante a pesquisa bibliográfica, estipulou-se o objetivo de analisar as questões pertinentes a divindade de Cristo e

\footnotetext{
1 BASTOS, Rogério Lustosa. Ciências humanas e complexidades: projetos, métodos e técnicas de pesquisa: o caos, a nova ciência. $2^{2}$ edição. Rio de Janeiro: E-papers, 2009. p.51.
}

Revista Pax Domini | Faculdade Boas Novas | v. 2 | p. 122 - 145 | mar. 2017 
do Espírito Santo a fim de apontar as soluções apresentadas nos concílios de Nicéia e Constantinopla. Sendo isto desenvolvido através da investigação das divergências entre Ário e Alexandre, a influência de Constantino na decisão conciliar e nos desdobramentos do concílio Niceno, as divisões teológicas do concílio Niceno, a influência de Atanásio no pensamento teológico dos pais capadócios. E, por fim serão apresentadas as soluções formuladas nos concílios de Nicéia e Constantinopla.

\section{ORIGEM E DESENVOLVIMENTO DA DOUTRINA: DIVERGÊNCIAS ENTRE ÁRIO E ALEXANDRE}

O século II apresenta uma cristologia pouco desenvolvida, ou seja, a divindade de Cristo não era claramente articulada. Com isso a doutrina da Trindade não aparecia de forma clara e objetiva, sendo tratada latente mente. ${ }^{2}$

A necessidade de aceitar a apresentação de um único Deus em três pessoas: Pai, Filho e Espírito Santo; culminou em muitas controvérsias e discussões que se desenvolveram por longos anos, até chegar-se a formulação do dogma da Trindade. Para os cristãos da época, esse processo formativo não se desenvolveu de modo simples e lógico, marcando assim, a história do cristianismo. A princípio, deve-se entender que os primeiros cristãos foram judeus, e sua ligação com um único Deus era extremamente forte. A essência monoteísta desses cristãos constituía um grande obstáculo para compreensão da junção de Jesus, na qualidade de Cristo, com Deus. ${ }^{3}$

A essência monoteísta fundamentada na religião de Israel, berço do cristianismo, repercutiu nos credos clássicos da cristandade, pois tinham por fundamento a declaração na crença num só Deus, criador dos céus e da terra. $A$ crença num único Deus, Pai e criador da humanidade são originárias do Antigo Testamento, não sendo constituintes da filosofia da época. ${ }^{4}$ Desse modo, a cristologia presente no século II foi marcada por vários movimentos cristãos-

\footnotetext{
${ }^{2}$ HORTON, Stanley M. [et. al...]. Teologia Sistemática. Rio de Janeiro: CPAD, 1996. p.165.

${ }^{3}$ LORENZEN, Lynne Faber. Introdução à Trindade. São Paulo: Paulos, 2002. p.13.

${ }^{4}$ KELLY, J. N. D. Patrística origem e desenvolvimento das doutrinas centrais da fé cristã. São Paulo: Vida Nova, 1994. p.61.
}

Revista Pax Domini | Faculdade Boas Novas | v. 2 | p. 122 - 145 | mar. 2017 
judaizantes. $\mathrm{O}$ ebionista, ${ }^{5}$ que negava completamente o caráter divino de Cristo. $\mathrm{O}$ docetismo ${ }^{6}$, considerava a humanidade de Cristo e que os seus sofrimentos foram irreais, apenas frutos de seu imaginário. ${ }^{7}$ Outro movimento que também deixou a sua marca na história concernente à testificação da divindade de Cristo, foi o gnosticismo. ${ }^{8}$ O gnosticismo chegou a dominar a tradição central, sendo um transporte do mundo bizarro de especulação cósmica:

O cristo divino desceu do pleroma, ou mundo espiritual de éons, e, por algum tempo (de acordo com Ptolomeu, entre batismo e paixão), esteve unido com personagem histórico Jesus; e, de acordo com a maioria dos relatos, o corpo deste último formou-se não de carne comum, mas de substância "psíquica". 9

Até este ponto o que se parece é que qualquer grupo de cristãos poderia criar uma corrente ideológica e expandi-la sem ser combatido por ninguém. Mas esses grupos ideológicos foram enfrentados pelos apologistas. ${ }^{10}$ Dentre os tantos apologistas, os que se inserem nesse estudo são: Justino, Irineu, Tertuliano e Orígenes.

Os apologistas também contribuíram muito para a história da teologia cristã na forma de uma reflexão inicial sobre as crenças mais importantes a respeito de Deus e de Jesus Cristo e, ao fazerem isso começaram a criar a base para a doutrina plenamente desenvolvida da Trindade, que ainda seria construída. ${ }^{11}$

O autor Roger Olson, ${ }^{12}$ faz uma apresentação sobre as contribuições dos

\footnotetext{
${ }^{5} \mathrm{O}$ nome ebionita é originado da palavra hebraica ebion, pobre. Existem duas seitas que aceitam de ebionitas: "aqueles que aceitam que Jesus nasceu de uma virgem e os que, não creem que Jesus nasceu desse modo, mas como todos os homens". (PADOVESE, p.46, 2004).

${ }^{6}$ Corrente de pensamento que afirmava que o corpo de Cristo não seria real, mas somente aparente (gr. dokein, "parecer") e que, portanto seriam aparentes os seus sofrimentos; ou, então, que o Redentor, que não poderia de modo algum sofrer, separado do homem que ele aparentaria ser. (FERGUSON, p.306, 2009).

${ }^{7}$ KELLY, Op. cit. p.103.

${ }^{8}$ Os gnósticos de movimento religiosos diversos que enfatizavam a salvação mediante a gnoses ou conhecimento, acima de tudo. $\mathrm{O}$ aspecto essencial do gnosticismo era o dualismo cosmológico oposição entre o mundo espiritual e o bom e o mundo material mau. (FERGUSON, p.457, 2009).

9 KELLY,1994 p.105

${ }^{10}$ Pequeno grupo de autores do século II que procuravam tornar o cristianismo inteligível (e aceitável) para um grupo greco-romano ou judeu, afim de estabelecer uma ponte entre essa religião "bárbara" e a cultura de sua época. (FERGUSON, p.82, 2009).

11 OLSON, Roger. História da Teologia Cristã. São Paulo: Editora Vida, 2001. p.65.

12 Roger Olson é professor de teologia de Bethel College, em St. Paul, Minnesota, EUA. É também editor da revista Christian Sholar's Review. Escreveu outros dois livros intitulados 20th-Century
}

Revista Pax Domini | Faculdade Boas Novas | v. 2 | p. 122 - 145 | mar. 2017 
apologistas a partir de suas defesas teológicas. Ele dá a Justino a reputação de "o apologista mais importante do século II" devido a sua defesa em favor de Cristo como Logos cósmico e de o cristianismo ser a filosofia verdadeira. Irineu criticou o gnosticismo reduzindo o a cosmovisão gnóstica. Tertuliano foi o que mais rejeitou a teologia instruída pela filosofia. Orígenes é erroneamente tido como um cristão que colocou a razão e a filosofia antes da fé. ${ }^{13} \mathrm{~A}$ partir deste ponto serão apresentadas as defesas dos apologistas em confronto com os pensamentos cristológico. Para Justino, em combate aos pagãos de sua época, a chave para desvendar os mistérios do evangelho cristão estava no entendimento do conceito de Cristo como o Logos de Deus. Justino foi o pioneiro a explicar o conceito do Logos e do Espírito em relação ao Pai. Porém, ficou Ihe faltando apenas explicar o Logos e o Espírito como duas entidades da Trindade. ${ }^{14}$

Irineu marcou o fim do século II. Ele combateu o gnosticismo, através de sua declaração da unicidade de Deus. Com esse pensamento monoteísta, Irineu concedeu a Igreja uma defesa contra o politeísmo. Ele resistia fervorosamente aos ensinamentos gnósticos, através de sua ênfase na plena unidade de Cristo, quanto sua plena divindade. ${ }^{15}$

O apologista que mais repercutiu na passagem do século II para o século III, foi Tertuliano de Cartago. Sua tarefa foi a de combater Praxeas. Esse combatente de Tertuliano desenvolveu uma doutrina que recebeu o nome de "patripassionismo" 16 . Com seu ensino Praxeas, afirmava que o Pai, o Filho e o Espírito Santo, eram os modos a partir dos quais Deus se manifestava, ou seja, às vezes era Pai, outras Espírito e em outras era o filho. Sendo assim, o Pai é quem sofreu a crucificação, pois o Filho é o Pai. ${ }^{17}$ Para combater o patripassionismo, Tertuliano apresentou uma fórmula que forneceu uma declaração nítida do monoteísmo orgânico:

theology e Who needs theology?, em co-autoria com Stanley J. Grenz. O dr. Olson tem artigos publicados nos periódicos The Scottish Journal of Theology e Perspective on Religious Studies.

${ }_{13}^{13}$ OLSON, Op. cit., p.57. et seq.

14 Ibidem., p.59.

${ }^{15}$ HORTON, 1996. p.166.

${ }^{16}$ Linha de pensamento que procurou unir a divindade do Filho com a unicidade do Pai ao declarar que as designações Pai e Filho eram simples modos, ou expressões, da manifestação de uma mesma pessoa divina. (FERGUSON, 2011. p.696.)

17 GONZÁLEZ, Justo L. História ilustrada do cristianismo: a era dos mártires até a era dos sonhos frustrados. 2a edição. São Paulo: Vida Nova, 2011.p.82

Revista Pax Domini | Faculdade Boas Novas | v. 2 | p. 122 - 145 | mar. 2017 
Todos [os três: o Pai, o Filho e o Espírito Santo] provêm de Um, pela unidade (procedente) da substância; mas o mistério da dispensação ainda deve ser guardado, que distribuiu a Unidade em uma Trindade, colocando na devida ordem as três Pessoas: o Pai, o Filho e Espírito Santo; três, porém, não em condição mas em grau, não na substância, mas na forma, não no poder, mas no aspecto e, não obstante, de uma substância, uma só condição e um poder. ${ }^{18}$

Último dos apologistas a ser apresentado é Orígenes. Esse apologista foi um dos maiores do século III. A maior preocupação de Orígenes se concentrava em desvendar os mistérios mais elevados de Deus e de sua criação. Afirmando que há uma independência entre o Pai e o Filho. A sua declaração final é que o Pai, o Filho, e o Espírito Santo são "três Pessoas" (hypostaseis)..$^{19}$ Vale também ressaltar que Orígenes deixou um problema no seu discurso. A sua formulação acerca do relacionamento entre o Pai e o Filho, era inconsistente. Assim, ele apresentava como um tipo de deidade de segunda categoria, distinto do Pai. Essa inconstância a respeito do subordinacionismo culminou numa reação maciça dos monarquianos ${ }^{20}$.

Apesar dos esforços dos apologistas em combater as muitas doutrinas, mesmo assim, os questionamentos acerca da divindade não se resolveram e, assim prosseguiram por longos tempos até que no século IV, passam por mais confrontos e debates que irão culminar na formulação dos primeiros concílios ecumênicos, Estes são considerados ecumênicos por que foram fieis a doutrina da igreja.

O século IV foi marcado por muitos questionamentos acerca da identidade de Jesus Cristo. Nesse tempo, as perguntas mais intrigantes buscavam esclarecer se Ele era ou não divinamente semelhante ao Criador e Senhor do céu. A partir disso tem-se: a introdução de termos como "da ousia ${ }^{21}$ do Pai" e "homoousios ${ }^{22}$ com o Pai" e o início dos debates entre Ário e Alexandre, culminando na formulação do dogma

\footnotetext{
18 OLSON, 2001, p.97.

${ }^{19}$ KELLY, 1994. p.96.

${ }^{20}$ Nome designados as heresias do século III cuja doutrina básica era a de que Deus é único e um princípio só de toda a existência, constituiu por si mesma toda a verdade aceita do monoteísmo ético do Antigo Testamento, herdada pelo cristianismo. (FERGUSON, 2011. p.695). HORTON, 1996. p.169.

${ }^{21}$ Termo amplamente utilizado na filosofia pré-cristã, cujo significado equivale aproximadamente, a "coisa real". Os cristãos foram, sem dúvida convencidos basicamente pelas Escrituras de que a palavra poderia e deveria ser usada a respeito de Deus. (FERGUSON, 2009, p. 944)

${ }^{22}$ Palavra usada para afirmar a plena divindade do Filho, como "de uma única substância" com o Pai. (FERGUSON, 2009, p. 944)
}

Revista Pax Domini | Faculdade Boas Novas | v. 2 | p. 122 - 145 | mar. 2017 
da trindade. ${ }^{23}$ Ário era originário da África, nasceu em torno de 260. Foi Padre na Igreja de Alexandria no começo do século IV, e foi na juventude partidário de Luciano de Alexandria. Segundo alguns estudiosos, foi por volta de 320 que Ário iniciou a difusão de sua doutrina sob inspiração do neoplatonismo, obtendo a aprovação de inúmeros sequazes, que por isso foram chamados de "arianos". ${ }^{24}$

Segundo a cristologia de Ário, o Verbo não é Deus em sentido rigoroso, mas uma espécie de "Deus" intermediário, ou seja, Cristo é uma criatura excelente, a melhor de todas; porém não é eterno, e sim a imagem do único Eterno. Para chegar a essa conclusão, Ário se baseou em Jo 16.28: "Eu saí do Pai e vim ao mundo". 25 Logo, Ário fortaleceu o seu punho argumentativo com base na Bíblia, revelando assim o seu profundo grau de conhecimento e estudo das Escrituras, ocasionando grande preocupação aos Trinitaristas. As discussões aos questionamentos acerca do caráter divino eram mútuas entre Ário e Alexandre. Ário acusava Alexandre de ser sabelianista ${ }^{26}$ por acentuar a unidade entre o Pai e Filho, deixando o Filho reduzido a uma posição inferior. Já Alexandre, acusava Ário de ser um repetidor da heresia adocionista. ${ }^{27}$

A reflexão de ambos se reduz ao pensamento de Orígenes. Ário, todavia, com base no medioplatonismo e num contexto de polêmica anti-sabeliana, radicalizou o subordinacionismo presente no mestre alexandrino. A ideia de que o Filho, por ser gerado, não pode ser coeterno com o Pai revelou-se um dos pontos centrais de seu pensamento. ${ }^{28}$

Em resposta às críticas de Ário acerca de Deus e de Jesus Cristo, o bispo Alexandre tentava corrigi-lo através de correspondências e sermões. $O$ bispo

\footnotetext{
${ }^{23}$ PELIKAN, Jaroslov. A tradição cristã - uma história do desenvolvimento da doutrina. São Paulo: Shedd Publicações, 2014. p.235.

${ }^{24}$ MORESCHINI, Cláudio., NORELLI, Eurico. História da Literatura Cristã Antiga Grega e Latina: II do Concílio de Nicéia ao início da Idade Média [TOMO 1]. São Paulo: Edições Loyola, 2000. p.50.

${ }^{25}$ GONZÁLEZ, Carlos Ignácio. Ele é a nossa a salvação. São Paulo: Edições Loyola, 1992. p.283.

${ }^{26}$ Originário de Sabélio. Essa doutrina ensinava que o Pai, o Filho e o Espírito Santo são uma só e mesma essência, três nomes apenas dados a uma só e a mesma substância. (BETTENSON, 2011, p.82)

${ }_{27}$ Termo comumente aplicado a ideia de que Jesus era meramente um homem comum, mas de virtudes ou proximidade com Deus, incomuns a que Deus "adotou" em filiação divina. (FERGUSON, 2009, p.32)

28 PADOVESE, Luigi. Introdução à Teologia Patrística. 2ª edição. São Paulo: Edições Loyola, 2004. p.70.
}

Revista Pax Domini | Faculdade Boas Novas | v. 2 | p. 122 - 145 | mar. 2017 
Alexandre, era uma pessoa meiga e tolerante e não tinha prazer em conflitos e muito se esforçou em corrigi-lo. Porém as atitudes pacíficas de Alexandre não surtiram muitos efeitos e, por isso, convocou Ário para um sínodo formado por cem bispos, para prestar os devidos esclarecimentos.

\begin{abstract}
Alexandre acusou Ário de ensinar que o Logos era caído da mesma forma que Satanás. Além disso, acusou Ário de repetir a heresia adocionista de Paulo de Samosata de forma um pouco mais sofisticada. A cristologia de Paulo foi condenada em um sínodo em 268 porque negava a divindade de Cristo e rejeitava a Trindade. A cristologia de Ário fazia o mesmo, embora afirmasse a preexistência do Logos como um grandioso ser celestial, coisa que o bispo Samosata não afirmava. ${ }^{29}$
\end{abstract}

Alexandre, condenou o arianismo. Porém, Ário, aferrado a ela, desprezou a condenação negando-se em obedecê-la. Isto com que o Alexandre convocasse um sínodo de quase 100 bispos africanos. Dos cem bispos convocados noventa e oito deles condenaram a doutrina de Ário. A insistência de Ário em defender sua doutrina, culminou na sua excomunhão. Mas ele, recorreu a seus companheiros e discípulos Luciano no oriente. Ário foi muito apoiado pelo bispo Eusébio de Nicomédia. Muitos bispos o seguiram, isto causou uma grande ruptura na unidade da igreja. ${ }^{30}$

A partir de todos os apontamentos já apresentados, entende-se que tanto a Alexandre como Ário, foram mutuamente influenciados pelos ensinamentos de Orígenes. O problema disto é que a ambiguidade do pensamento de Orígenes muito repercutiu nas disputas entre Ário e Alexandre. Sob a influência do pensamento de Orígenes, Alexandre declarava que e o Filho era eterno, da mesma essência do Pai incriado. Por sua vez Ario, considerava o filho totalmente homem e divino por sua subordinação, e obediência à vontade do Pai. Por fim pode-se entender que os questionamentos acerca da divindade de Cristo e do Espírito Santo, possuem suas raízes fincadas desde a era dos primeiros cristãos. Esses cristãos possuíam pensamentos que divergiam entre si que culminou na formação de vários grupos (ebionitas, docetistas, patripassianistas, arianistas), onde cada um constituía as suas

\footnotetext{
${ }^{29}$ OLSON, 2001. p.49.

30 GONZÁLEZ, 1992. p.283.
}

Revista Pax Domini | Faculdade Boas Novas | v. 2 | p. 122 - 145 | mar. 2017 
próprias ideias acerca de Cristo.

\title{
3 A INFLUÊNCIA DO IMPERADOR CONSTANTINO NO CONCÍLIO DE NICÉIA
}

O imperador Constantino é um personagem muito importante na história do cristianismo, pois mesmo sendo pagão, estimulou a religião cristã como forma de agregação do império romano. É marco do elo da transformação da instância conciliar em órgão do Estado.

\begin{abstract}
A transformação da instância conciliar em órgão, que estará completada e plenamente manifestada já no Niceno I, foi preparada pelos acontecimentos ligados ao primeiro conflito eclesial que Constantino teve que enfrentar, logo que seu poder se afirma no ocidente e, com isso, a virada que favoreceu 0 cristianismo. ${ }^{31}$
\end{abstract}

A relação de Constantino com o cristianismo se inicia com a visão que teve de uma cruz. Tal visão foi considerada como um sinal e, ordenou que os soldados pintassem em seus escudos a palavra Cristo em letras gregas. Constantino derrotou Licínio, e entrou em Roma vitorioso. ${ }^{32}$

Após Constantino estabelecer a tolerância religiosa e dar um fim a perseguição do Império romano pagão, ele concede através do Edito de Milão a liberdade de consciência e de culto a todas as religiões e a restauração das propriedades dos cristãos. Os cristãos dessa época estavam vivenciado um novo tempo, onde não mais temeriam a perseguição. Tendo consicência desse tempo de paz que Constântino concedera aos cristãos, o bispo Eusébio de Cesária viu no imperador a figura de um amigo dos cristão e amado por Deus. Até então Eusébio, não era um homem público ou político da lgreja. Ele era apenas um teólogo, mantendo-se sempre firme em defender a verdade e os direitos da igreja cristã. ${ }^{33}$

\footnotetext{
Mas aos oprimidos não restva esperança de salvação das crueldades que suportaram das bestas selvagens. Quando também Constatntino, o protetor do bem, combinando seu ódio da maldade com o amor da bondade, saiu com seu fiho Crispo, o César mais benevolente, para estender o braço salvador a todos os que estavam perecendo. Então, o pai e o filho, de certo modo como Deus, o Rei universal, e o seu Filho, o nosso salvador, como

${ }^{31}$ ALBERICO, Giuseppe. História dos Concílios ecumênicos. 4ª edição. São Paulo: Paulus, 2011. p.17.

${ }^{32}$ SOUZA, Alex Amorim de. O segundo Deus. Porto Alegre: Redes Editora, 2008. p.89.

${ }^{33}$ CAMPENHAUSEN, Hans von. Os pais da Igreja. Rio de Janeiro: CPAD, 2013. p.62.
}

Revista Pax Domini | Faculdade Boas Novas | v. 2 | p. 122 - 145 | mar. 2017 
líder e ajudador deles, formando o exército de todos os lados cotra os inimigos de Deus, ganharam uma vitória fácil; todas as coisas Ihes foram favorecidas por Deus no conflito de acordo com o que desejavam. ${ }^{34}$

Ainda que tenha sido asperamente criticado pelos elogios que fizera ao imperador e pela falta de sinceridade de seu 'bizantismo', a opinião declarada de Eusébio é um dos pontos cruciais da relação entre o império e a igreja. O imperador deu grande importância as declarações lisonjeosas e ao apoio que the fora concedido pelo bispo Eusébio. ${ }^{35}$ Eusébio lutava por uma civlização moral unida a uma igreja mundial. $\mathrm{E}$, isso só seria possivél através do imperador, que promoveria a unidade permanente de uma ordem cristã, e de uma paz mundial sagrada. Porém toda essa promoção de união e paz estavam sendo ameaçadas pela controvéria ariana. O resultado disso é que o arianismo estava divindo a igreja grega justamente no momento da vitória de Constântino. ${ }^{36}$ Quando o imperador recorreu à fé cristã, contava com a igreja para dar nova vida ao Império debilitado. Mas, para fazer isso, a própria igreja precisava se unir. Um cristianismo em discórdia e dividido não podia unir o Império fragmentado 37

A verdade é que tanto Eusébio quanto Constantino partilhavam do mesmo pensamento, ambos buscavam promover a paz e encerrar os conflitos provomovidos pelos arianos. Foi Constântino quem apontou uma solução para encerrar esses conflitos convocando um conscilio entre os bispos da igreja cristã. Foi em 325, na cidade de Nicéia que foi realizado primeiro concílio ecumênico. Para este, foram convocados cerca de trezentos bispos. O próprio imperador esteve presente na assembleia e presidiu seus procedimentos. Dentre os convocados para o concílio de Nicéia estava um pequeno grupo inteiramente arianos liderado por Euséibio de Nicomédia, já que Ário por não ser bispo, não poderia participar. Outro grupo presente era o de Eustácio de Antioquia e Marcelo de Ancira, fervorosos apoiadores de Alexandre. A parte majoritária era possivelmente a de Eusébio de Cesaréia, que eram os mais conservadores. ${ }^{38}$

\footnotetext{
${ }^{34}$ CESARÉIA, Eusébio de. História eclesiástica. Rio de Janeiro: CPAD, 2011. p.402.

${ }^{35}$ CAMPENHAUSEN Op. cit., p.63.

${ }^{36}$ Ibidem, 2013. p.63.

${ }^{37}$ SHELLEY, Bruce L. História do cristianismo de todos: uma narrativa do desenvolvimento da Igreja Cristã através dos séculos. São Paulo: Shedd Publicações, 2004. p.112.

${ }^{38}$ WALKER, Wiliston. História da igreja cristã. 3를 edição. São Paulo: ASTE, 2006. p.159
}

Revista Pax Domini | Faculdade Boas Novas | v. 2 | p. 122 - 145 | mar. 2017 
Logo após a abertura do concílio, a assembleia foi logo apontando o seu direcionamento que era o de rejeitar a confissão de fé aferrada pelos arianos. Eusébio busca eliminar qualquer suspeita sobre si e inicia a leitura do credo batismal de sua cidade natal. $\mathrm{O}$ imperador e os bispos por ele liderados, concordaram que o credo lido por Eusébio era totalmente ortodoxo, porém não resolvia explicitamente a fundamentação de Ário. ${ }^{39}$

O credo de Cesáreia: Cremos em um só Deus, Pai onipotente, criador de todas as coisas visíveis e invisíveis; e em um só Senhor Jesus Cristo, Verbo de Deus, Deus de Deus, Luz de Luz, Vida de Vida, Filho unigênito, primogênito de toda a criação, por quem foram feitas todas as coisas; o qual foi feito carne de carne para nossa salvação e viveu entre os homens, e sofreu, e ressuscitou ao terceiro dia, e subiu ao Pai e novamente virá em glória para julgar os vivos e os mortos; cremos também em um só Espírito Santo. ${ }^{40}$

Porém, ao que se parece, a intenção do imperador e dos bispos por ele liderados, é a de repudiar o ensino de Àrio, mas sem excluir o posiocionamento oriental tradicional. Para isso, eles pegam um outro código batismal, muito similar ao de Eusébio e o alteram afim de atingir os seus próprios propósitos. Com isso eles criam um novo tipo de confissão, não litúrgica. E, ao final, adicionam "uma série curta de anátemas que condenavam diretamente as proposições básicas afirmadas pelos arianos". 41

Credo Niceno elaborado no Primeiro Concílio de Nicéia (325): cremos em só Deus, Pai onipotente, criador de todas as coisas visíveis e invisíveis; e em um só Senhor Jesus Cristo, o Filho de Deus, gerado pelo Pai, unigênito, isto é, da substância do Pai, Deus de Deus, Luz de Luz, Deus verdadeiro de Deus verdadeiro, gerado não feito, de uma só substância com o Pai, pela qual foram feitas todas as coisas, as que estão no céu e as que estão na terra; o qual, por nós homens e por nossa salvação desceu, se encarnou e se fez homem, e sofreu e ressuscitou ao terceiro dia, subiu ao céu, e novamente deve vir para julgar os vivos e os mortos; e no Espírito Santo. E a quantos dizem: "Ele era quando não era", e "antes de nascer, Ele não era", ou que "foi feito do não existente", bem como a quantos alegam ser o filho de Deus "de outra substância ou essência", ou "feito", ou "mutável", ou "alterável" a todos estes a Igreja Católica e Apostólica anatematizada. ${ }^{42}$

\footnotetext{
39 Ibidem. p.159

${ }^{40}$ BETTENSON, Henry. Documentos da Igreja Cristã. 5a edição. São Paulo: ASTE, 2011. p.61

${ }^{41}$ WALKER, 2006. P.159

42 BETTENSON, 2011, p.62.
}

Revista Pax Domini | Faculdade Boas Novas | v. 2 | p. 122 - 145 | mar. 2017 
Enquanto o concilio de Nicéia estava em plena efervescência, do lado de fora, Ário estava a pôr a sua doutrina em forma de música, espalhando o seu pensamento teológico:

Deus incriado fez o Filho / princípio das coisas criadas, / E pela adoção Deus fez o Filho / Numa projeção de si mesmo. / Todavia, a substância do Filho está / Afastada da substância do Pai: / O Filho não é igual ao Pai, / Nem partilha da mesma substância. / Deus é o Pai de toda a sabedoria, / E o Filho é o mestre de seus mistérios. / Os membros da Trindade Santa / Partilham de glórias desiguais. ${ }^{43}$

O concílio de Nicéia não se desenvolveu de modo pacífico. Em virtude da extensão dos debates, paulatinamente a ideia de se desenvolver um credo unificante e compulsório que sumarizasse "a fé antiga da igreja" foi ganhando forças, culminando assim na formulação do Credo de Nicéia.

Depois de algumas discussões e pouca concordância, o próprio Constantino propôs que o novo credo incluísse a afirmação de que o Filho é o homoousios - consubstancial com o Pai. É possível que Ósio tivesse recomendado essa linguagem e que tivesse sido influenciado nesse sentido por Alexandre e Atanásio. Outra origem possível era o bispo Eusébio de Cesária. $^{44}$

O termo homoosios foi amplamente rejeitado pelo arianismo, por ser uma demonstração da explicação redutiva utilizada por Eusébio na Carta à Igreja de Cesária. Esta carta trazia a interpretação dada por Constantino em resposta às dúvidas expressas pelos padres conciliares. $O$ imperador assegurou que homoosios não deveria ser entendido de modo materialista, tal como ocorria em relação aos corpos, porque a geração do Filho pelo Pai, não produz incisão ou divisão na divindade. ${ }^{45}$

Nesse contexto o que se pode dizer é que Constantino exerceu grande influência na formulação do Concílio de Nicéia, pois foi ele quem nomeou uma comissão de bispos cuja função era a de redigir o texto do credo que deveria ser assinado por todos os bispos ali presentes, e também pelos que não conseguiram comparecer ao concílio. O credo de Nicéia se fundamentou em estabelecer a grande

\footnotetext{
${ }^{43}$ NOLL, Mark A. Momentos decisivos na História do Cristianismo. São Paulo: Editora Cultura Cristã, 2000, p.58.

${ }^{44}$ OLSON, 2001, p.158.

${ }^{45}$ ALBERICO, 2011. p.33.
}

Revista Pax Domini | Faculdade Boas Novas | v. 2 | p. 122 - 145 | mar. 2017 
ortodoxia da igreja contra o arianismo. E as decisões da igreja acerca da divindade de Cristo teve tanto valor religioso quanto político. ${ }^{46}$

O valor político de Nicéia é indicado nos acontecimentos da metade do século IV. A maior questão colocada era a da conversão de Constantino e da transição do império sob a decisão de aderir o cristianismo e, de não mais persegui-lo. Os bispos se consideraram satisfeitos com o credo Niceno, sendo assinado por quase todos, ficando entendido como sendo uma expressão genuína de sua fé. Dos bispos ali presentes somente alguns poucos se recusaram à assinar o credo, um deles foi Eusébio de Nicomédia (grande amigo de Ário), isso Ihes resultou em condenação, depostação do cargo e exílio de suas cidades. ${ }^{47}$

Esse período ficou marcado com as novas relações da lgreja com o Estado, o que implica dizer que o fracasso ou sucesso de uma doutrina ficava a mercê do favor do imperador, acalorando ainda mais as divisões. Como resultado do concílio de Nicéia, o arianismo propriamente dito foi lançado na obscuridade, porém os conflitos emergentes do concílio só serviram ressaltar as vastas divisões teológicas que foram profundamente arraigadas nas fileiras de seus adversários. ${ }^{48}$

Sob a presidência do próprio imperador Constantino, o concílio de Nicéia foi iniciado em 20 de maio de 325 e, foi concluído em 25 de julho do mesmo ano. 0 concílio também foi prosseguido por Ósio de Córdova, fiduciário do imperador. Niceia deixou formulado um "símbolo", ou seja, um compêndio das verdades de fé. ${ }^{49}$

Shelley e Walker são consonantes ao afirmar que como foi visto até aqui, grandes foram os conflitos gerados pelo concílio de Nicéia. E, resta agora responder quais foram os resultados desse concílio. O concílio de Nicéia alcançou o objetivo de excluir o arianismo e forneceu a igreja oriental uma fórmula de comum acordo entre todos, declarando contra Ário que Cristo é completamente divino. Sobre o Espírito Santo não foi apresentado nenhum argumento, sendo deixado simplesmente como uma crença. Uma série de cânones foram estabelecidos a partir do concílio. A autoridade das igrejas locais e de seus bispos passaram a ter limitações, sendo

\footnotetext{
${ }^{46}$ OLSON, 2001. p. 160.

${ }^{47}$ GONZÁLEZ, Justo, 2011. p.170.

48 KELLY, 1994. p.179.

${ }^{49}$ MORESCHINI, 2000. p. 53.
}

Revista Pax Domini | Faculdade Boas Novas | v. 2 | p. 122 - 145 | mar. 2017 
posto um veto sobre a eleição e ordenação de bispos em sua área. ${ }^{50}$

Ao contrário da propagando feita por Eusébio de Cesaréia - que enfatizava Constantino como o defensor do cristianismo, o historiador Justo González ${ }^{51}$ afirma que Eusébio de Cesaréia era conhecedor do espírito sanguinário e da incontrolável ira de Constantino, porém essas falhas do caráter do imperador são omitidas por Eusébio. ${ }^{52}$

A verdade dos fatos é que o imperador se beneficiou dos afagos que Eusébio de Cesaréia lhe fizera e se investindo da oportunidade de formular o concílio, usou-o como ferramenta para legitimar o seu poder político e militar. O resultado disso foi o detrimento da unidade cristã.

A igreja dos tempos de Constantino não era apenas constituída pela parte hierarquizada formada pelo clero eclesiástico. A maioria da igreja era formada por trabalhadores rurais, pessoas simples e comuns. As necessidades dessas pessoas em momento algum foram apresentadas no concílio. Os problemas enfrentados pelos pobres eram concernentes aos impostos, aumento dos preços e fixação compulsória das pessoas na terra em que trabalhavam. ${ }^{53}$

No entanto vale ressaltar que teologia não pode ser separada do social. Assim pode-se constatar que unidade imperial muito conflita com a unidade cristã. Isso por que enquanto, após derrotar Maxêncio (grande perseguidor dos cristãos), Constantino oferecia graciosamente o tesouro imperial aos bispos ele próprio estava perseguindo os donatistas na África, sendo que de acordo com a propaganda oficial Constantino era apresentado como defensor do cristianismo.

A partir da análise histórica do concílio de Nicéia pode-se afirmar que esse evento foi um marco na história do cristianismo, iniciando através de Constantino as novas relações entre a Igreja e o Estado. Esse elo só foi possível através da pessoa de Eusébio de Cesaréia em virtude dos seus altos elogios e afirmações honrosas

\footnotetext{
${ }^{50}$ SHELLEY, 2004. p.128. WALKER, 2006, p.160.

51 Justos González, nascido em Cuba e radicado nos Estados Unidos, é graduado pelo Seminário Unido de Cuba, com mestrado e doutorado pela Universidade Yale. Tem experiência de ensino de história da igreja em diversos seminários da América Central e dos Estados Unidos, destacando-se ainda por sua prolífica produção literária.

${ }^{2}$ GONZÁLEZ, Justo. 2011,. p.144.

${ }^{53}$ HINSON, E. Gleann., SLEPLERSKI, Paulo. Vozes do cristianismo primitivo: o cristianismo como movimento que celebra sua unidade na diversidade, feito por indivíduos comuns, rumo à institucionalização. São Paulo: Arte Editorial, 2010, p.129.
}

Revista Pax Domini | Faculdade Boas Novas | v. 2 | p. 122 - 145 | mar. 2017 
sobre o Imperador. Sendo assim, Eusébio influenciou o clero de sua época fazendo com que concedessem a Constantino todo o apoio que precisasse. E, assim Constantino se aliançou a Igreja pondo um fim às perseguições.

$\mathrm{O}$ apoio concedido por Constantino ao cristianismo foi o ponto final para as perseguições sobre a Igreja. Porém no decorrer desse tempo, os fervores teológicos surgidos nesse período, acabaram ameaçando a estabilidade de Constantino. Com isso, o imperador convoca o primeiro concílio ecumênico afim de sanar as batalhas teológicas. Porém, Constantino utiliza o concílio de Nicéa como uma ferramenta para estabelecer sobre a igreja o seu poderio como imperador.

\section{DESDOBRAMENTOS DO CONCÍLIO DE NICÉIA E SUAS DIVISÕES TEOLÓGICAS ATÉ CONSTANTINOPLA}

Mesmo com a obscuridade do arianismo, não foi o suficiente para extirpar as divisões teológicas, que por sinal, arraigaram-se nas fileiras de seus opositores. $\mathrm{O}$ elo histórico marcado pelas novas relações entre a Igreja e o Estado, muito colaboravam para o sucesso ou fracasso doutrinário que eram dependentes do favor do imperador.

Como previamente dito, o bispo Eusébio de Nicomédia, foi um dos poucos a não assinar o credo de Nicéia e, por isso recebeu do imperador Constantino as devidas punições. Porém, Eusébio de Nicomédia era um político muito hábil e, ao que parece era parente distante de Constantino. E, estrategicamente usou de sua afinidade para reconquistar a simpatia do imperador, que logo the deu autorizações para retornar a Nicomédia. ${ }^{54} \mathrm{O}$ imperador muito se preocupou em estabelecer a paz e a unificação da Igreja Imperial, por isso a decisão tomada no concílio de Nicéia não foi acidental, sendo o resultado de medidas e pressões táticas. E, Constantino só conseguiria essa pacificação através da condenação de Ário. ${ }^{55}$

Porém, mesmo Ário sendo condenado, o imperador não alcançou os objetivos que almejara. Com isso, passou a ser persuadido pelos seus conselheiros a expandir os limites do entendimento na igreja universal. Sendo assim, Constantino

${ }^{54}$ GONZÁLEZ, Justo, 2011. p.170

${ }^{55}$ CAMPENHAUSEN, 2013. p.68.

Revista Pax Domini | Faculdade Boas Novas | v. 2 | p. 122 - 145 | mar. 2017 
volta atrás revogando a decisão que havia tomado anteriormente. ${ }^{56}$

Com a revogação da decisão de Constantino, Ário foi favorecido tendo assim a liberdade para expandir seu argumento teológico. No entanto, a ordem formal para o reconhecimento da absolvição de Ário não chegou num momento propício. Pois justamente nesse período, o bispo Alexandre (grande oponente do arianismo) falece antes mesmo de responder o comunicado do imperador, ficando sobre o seu sucessor Atanásio, o encargo de tomar esta decisão. ${ }^{57}$ A Atanásio coube a responsabilidade de ser mais um grande defensor da causa nicena, um subsequente da controvérsia ariana.

Eusébio de Nicomédia e os demais dirigentes arianos sabiam que Atanásio era um dos seus inimigos mais temíveis. Por isso, começaram logo a fazer todo o possível para destruí-lo fazendo circular boatos de que praticava a magia e que tiranizava seus súditos entre os cristãos do Egito. ${ }^{58}$

As calúnias sobre Atanásio foram tão grandes a ponto de Eusébio de Nicomédia e seus seguidores o acusarem de ter ameaçado de cortar o suprimento dos grãos do Egito para a capital. Com isso, Constantino passou a ser persuadido ao ponto de sem nenhuma investigação aceitar as calúnias. O resultado disso, a Atanásio foi posto em exílio pelo imperador. ${ }^{59}$

Atanásio foi duramente perseguido e procurado em todos os lugares. Durante os seus anos de lutas, Atanásio, deu-se conta de que a razão de tanta oposição ao credo de Nicéia estava relacionada com o medo da afirmação de que o Filho era da mesma substância do Pai pudesse ser compreendida como querendo dizer que não há distinção alguma entre o Pai e o Filho. ${ }^{60}$ O que mais marcou os períodos das lutas de Atanásio em defender o credo de Nicéia era com passar dos tempos, novos domínios imperialistas surgiriam - dentre eles se destacam Constantino II, Constante e Constâncio, filhos e sucessores do imperador Constantino.

Constantino havia dividido o Império entre seus filhos, e isto levou a uma

\footnotetext{
${ }^{56}$ CAMPENHAUSEN, op. cit., loc. Cit.

57 lbid., p. 69.

${ }^{58}$ GONZALÉZ, Justo, 2011. p.181

59 WALKER, 2006. p.162.

60 GONZALÉZ, Justo, op. cit., p.183.
}

Revista Pax Domini | Faculdade Boas Novas | v. 2 | p. 122 - 145 | mar. 2017 
perda de unidade na política eclesiástica do Estado. Cada legislador em separado favorecia a tendência predominante em sua parte do império e esforçava-se para promove-la da melhor maneira nas regiões vizinhas. ${ }^{61}$

Já que nos tempos de Constantino, muitos bispos da fé nicena foram exilados, inclusive Atanásio. Agora, com império nas mãos dos filhos de Constantino, esses novos imperadores no início de seu reinado conjunto permitiram o retorno dos bispos exilados. ${ }^{62}$ Porém a decisão do imperador Constâncio, não foi nada permanente. Pois a relação entre Constâncio e Atanásio era muito turbulenta. Esse imperador simbolizava o principal foco de resistência da ortodoxia trinitária ante o arianismo e o semi-arianismo. ${ }^{63}$

Neste ponto a opinião de Constâncio é muito influente, pois ele se impõe a negar o termo homoousios que fora proposto por seu pai Constantino. Argumento de Constâncio era oposto com a seguinte regra: "Não quero que sejam usadas palavras que não estão na Escritura". ${ }^{64}$

Enquanto isto, de seu exílio no deserto egípcio defendendo a linguagem de Nicéia. Para Atanásio, como ele era veloz em dizer, homoousios não significava que o Filho é "idêntico com o pai." Em vez disto, significativa que o Logos está "em posse completa de algo que pertence ao Pai"; que existe uma "similaridade inalterável - para não dizer identidade - de ... qualidades entre, ainda que o Logos "tenha do Pai o que quer que ele possua". ${ }^{65}$

Neste tempo, o arianismo chegou ao seu apogeu, passando a ser defendido pelo Estado, o que acumulou à Atanásio mais perseguições, fazendo-o fugir em busca de refúgio entre os monges do deserto.

A política imperial já não disfarçava seu apoio aos arianos. Mais tarde, até mesmo o ancião Óssio de Córboda e o bispo de Roma, Libério, assinaram confissões de fé arianas. Eram muitos os bispos e os demais líderes eclesiásticos que estavam convictos de que o arianismo não era aceitável, mas era difícil fazer oposição quando o Estado apoiava tão decididamente. ${ }^{66}$

Mediante a situação descrita acima, mesmo assim, nos cinquenta anos seguintes ainda não estava claro quem ganharia a disputa contra o arianismo. Pois

\footnotetext{
${ }^{61}$ CAMPENHAUSEN, 2013. p. 71.

62 WALKER Op. cit., p.163.

63 OLSON, 2001, p.168.

${ }^{64}$ PELIKAN, 2014, p.220.

${ }^{65}$ WALKER, 2006, p.166.

${ }^{66}$ GONZALÉZ, 2011, p.183.
}

Revista Pax Domini | Faculdade Boas Novas | v. 2 | p. 122 - 145 | mar. 2017 
nesse período Atanásio foi banido cerca de cinco vezes; sendo que em cada retorno de uma expulsão sempre havia mudanças de imperadores ou uma mudança na composição do grupo eclesiástico. Com isso, Atanásio ficava cada vez mais distante dos privilégios imperiais, sentindo-se abandonando por todos os seus partidários. ${ }^{67}$

É importante destacar que embora Atanásio tenha tido grande êxito em defender o credo Niceno, não foi ele quem formulou plenamente a doutrina da Trindade, e nem tampouco incluiu explicitamente o papel do Espírito Santo, a natureza das três pessoas e sua unidade da Divindade. ${ }^{68}$ Porém, Atanásio deixou em suas defesas fundamentos para os teólogos posteriores, tais como os pais capadócios. ${ }^{69}$ Nisto deve-se considerar que tanto Atanásio quanto os pais capadócios lançaram grande alicerce para a confirmação do dogma trinitário em Constantinopla.

As formulações no tocante a doutrina da Trindade, incluindo o papel do Espírito Santo, a natureza de três pessoas e sua unidade na Divindade, serviu de alicerce para os seus pais capadócios que a desenvolveram e defenderam. Os pais capadócios além de esclarecer e defender a Trindade, tinham também o objetivo de sistematizar a fé da igreja e fazer dela uma exposição com maior clareza lógica possível. ${ }^{70}$

A salvação do mundo é o ponto pelo qual se inicia a ideia da Trindade. Sua explicação estava centrada na compreensão do relacionamento de Deus com o mundo, tornando possível essa salvação. Contudo era necessário distinguir entre a natureza divina (a ousía, essência) de Deus e as instâncias concretas da presença de Deus (as hypostasis, pessoas). De acordo com Atanásio, ambas, essência e as hypostasis são plenamente Deus, pois sem estas, Cristo - que é tido como a segunda pessoa da Trindade, não poderia produzir salvação. ${ }^{71}$

Atanásio completa seu ensino sobre Trindade: tudo o que o Pai efetua no que diz respeito a criação, ao governo do universo ou a redenção, Ele realiza pela sua palavra; e tudo o que a palavra opera, Ela o faz pelo

\footnotetext{
${ }^{67}$ SHELLEY, 2004, p.116.

${ }^{68}$ OLSON, 2001. p.172.

69 São conhecidos por capadócios porque vieram da região da Capadócia na Ásia Menor Central (Turquia) e ali exerceram seus cargos eclesiásticos. (OLSON, p.178, 2001).

${ }^{70}$ Ibidem., p.179.

${ }^{71}$ LORENZEN, 2002. p.21.
}

Revista Pax Domini | Faculdade Boas Novas | v. 2 | p. 122 - 145 | mar. 2017 
Espírito. "A santa e bendita Tríade é indivisível e é uma em si mesma. Quando se faz menção do Pai a palavra também está incluída, como também o Espírito está no Filho. Se o Filho é citado, o Pai está no Filho, e o Espírito não está fora da palavra. Pois a uma só graça que se realiza a partir do Pai, por meio do Filho, no Espírito Santo."72

J. N. D Kelly ${ }^{73}$ afirma que Atanásio assumiu a liderança na defesa do homoousion do Espírito, sendo tal tarefa completada, de modo cauteloso e ponderado, pelos pais capadócios. Os pais capadócios configuram o maior ato no trabalho de consolidação da fé nicena. Esses três pensadores gregos: Basílio de Cesaréia, Gregório de Nazianzeno, e Gregório de Nissa; eram amigos de Atanásio e muito contribuíram no desenvolvimento do seu pensamento teológico, através da criação de fórmulas que tornaram possível a maior parte do consenso dos teólogos orientais em torno da questão trinitária. ${ }^{74}$

Os pais Capadócios tomaram para si a tarefa de definir claramente a unidade e a diversidade existentes no Ser Divino, inclusive a terminologia adequada para isto, ou seja, a de que em Deus há três hipóteses e apenas uma "ousia" ou essência divina. Foram defensores dedicados do homoousion, e haviam percebido que a identidade de substância deve decorrer da doutrina de que o pai e o filho partilham da mesma divindade. ${ }^{75}$

Os pais capadócios foram muito enfáticos em defender a unidade da divindade do Pai. Basílio afirmava que o Pai era um determinado poder que de sobremaneira subsistia sem ser gerado nem ter uma origem; o Filho e o Espírito de modo particular tinham origem diferentes. Gregório de Nazianzo classificou o Pai como "maior" em diferenciação aos "iguais", sendo Filho e Espírito estes os "iguais", por virem do Pai. E por fim Gregório de Nissa, apresenta o Pai como "a fonte de poder", o Filho sendo o poder do Pai e o Espírito Santo como o Espírito de Poder. ${ }^{76}$

Como apresentado anteriormente, o credo niceno (325) faz uma mera

\footnotetext{
72 KELLY, 1994. p.195.

73 Jonh Norman Davidson Kelly (1909-1997), membro da Academia Britânica, foi um destacado erudito da Faculdade de Teologia da Universidade de Oxford. Escreveu muito sobre as primeiras confissões de fé, além de comentários bíblicos e estudos biográficos de Jerônimo e Crisóstomo. Foi membro fundador do conselho acadêmico do Instituto para Estudos Teológicos Avançados de Jerusalém.

${ }^{74}$ MATOS, Alderi Souza de. Fundamentos da teologia. São Paulo: Mundo Cristão, 2008. p.65.

75 KELLY, op. cit., p. 180.

${ }^{76}$ PELIKAN, 2014, p.232.
}

Revista Pax Domini | Faculdade Boas Novas | v. 2 | p. 122 - 145 | mar. 2017 
menção ao Espírito Santo, não Ihe concedendo nenhuma função. Porém, foram os pais capadócios que escreveram em favor da divindade do Espírito Santo. Sendo Basílio o primeiro a insistir na divindade do Espírito Santo. Gregório Nissa descreveu o Espírito Santo como sendo o dador de vida. Gregório Nazianzo descreveu o Espírito Santo sendo originário do Pai de modo diferente do Filho e, para isso acrescentou o termo "procede". ${ }^{77}$

Em seus argumentos os capadócios defendiam que a unidade do ser ou natureza de Deus implicam na unidade da atividade ou operação de Deus. Assim, as três pessoas, não são distintas uma das outras por se engajarem em diferentes atividades. Sendo todas relacionadas de modo distinguíveis, em cada ação divina. ${ }^{78}$

Os capadócios usavam analogia social, mais entendiam que as diferenças entre as três "pessoas" sagradas existiam somente em suas relações sagradas internas. Não esistem três deuses. Deus é um ser sagrado com ralações sagradas. Deus é um ser sagrado com três mensageiros: um Ente supremo em três "pessoas". ${ }^{79}$

Os resultados da obra teológica dos pais capadócios só foram manifestos após a derrota e morte do imperador Valente pelos visigodos. Com a morte de Valente, Graciano que era o imperador sobrevivente, ficou encarregado de indicar um novo augusto para o Oriente. Teodósio (379-395) foi o selecionado para assumir esse ofício, trazendo consigo a vantagem de ser favorável a clássica causa Nicena. ${ }^{80}$

Teodósio ao assumir a função de imperador, já que era favorável a causa nicena, chama Gregório de Nazianzo para participar do Concílio de Constantinopla em 381 . Esse concílio foi realizado para selar o triunfo da posição Nicena. ${ }^{81}$

Nesse ano, o imperador Teodósio fez da crença no cristianismo uma questão de autoridade imperial: É nossa vontade que todos os povos

\footnotetext{
77 LORENZEN, 2002, p.35.

78 WALKER, 2006. p.171.

${ }^{79}$ SHELLEY, 2004. p.118.

80 WALKER, op. cit., loc. cit.

${ }^{81}$ LORENZEN, 2002. p.34.
}

Revista Pax Domini | Faculdade Boas Novas | v. 2 | p. 122 - 145 | mar. 2017 
que governamos pratiquem essa religião que o divino Pedro, 0 Apostolo, transmitiu aos romanos. Devemos acreditar na única Divindade do pai, do Filho e do Espirito Santo, sob a ideia da majestade e da Santa trindade. Para Teodósio, havia uma estreita ligação entre sua própria vontade e a de Deus. Tratava-se de uma ligação implícita no império Cristão. ${ }^{82}$

O Concílio de Constantinopla foi uma honra memorável aos esforços de Atanásio e dos pais capadócios, pois condenou uma de vez por todas todos os tipos de subordinacionismo e sabelianismo. Assim credo de Constantinopla veio revogar o credo niceno com o acréscimo de um terceiro artigo tratando do Espírito Santo e da igreja. ${ }^{83}$ Segue abaixo o credo de Constantinopla:

\begin{abstract}
Ampliado no Primeiro Concílio de Constantinopla (381): Cremos em um Deus, Pai todo-poderoso, criador do céu e da terra, de todas as coisas visíveis e invisíveis; e um Senhor Jesus Cristo, o unigênito Filho de Deus, gerado pelo Pai antes de todos os séculos, Luz de Luz, verdadeiro Deus de verdadeiro Deus, gerado, não feito, de uma só substância com o Pai, pelo qual todas as coisas foram feitas; o qual, por nós homens e por nossa salvação, desceu dos céus, foi feito carne do Espírito Santo e da Virgem Maria, e tornou-se homem, e foi crucificado por nós sob o poder de Pôncio Pilatos, e padeceu, e foi sepultado, e ressuscitou ao terceiro dia conforme as Escrituras, e subiu aos céus, e assentou-se à direita do Pai, e de novo há de vir com glória para julgar os vivos e os mortos, e o seu reino não terá fim; e no Espírito Santo, Senhor e Vivificador, que procede do Pai, que com o Pai e o Filho conjuntamente é adorado e glorificado, que falou através dos profetas; e na lgreja una, santa, católica e apostólica; confessamos um só batismo para remissão dos pecados. Esperamos a ressurreição dos mortos e a vida do século vindouro. ${ }^{84}$
\end{abstract}

O concílio de Constantinopla em 381 completa o Credo com o artigo sobre o Espírito Santo. Este foi o segundo concílio ecumênico da igreja cristã, foi responsável pelos retoques finais do Credo de Niceia, estabelecendo a doutrina formal da Trindade desenvolvida por Atanásio e seus amigos. ${ }^{85}$

É evidente, por isso, que a época que segue a Niceia pode ser vista, em grandes linhas, como história da recepção do concílio, processo mediante o qual as Igrejas, em meio a uma série de dificuldade e lutas,

\footnotetext{
82 SHELLEY, op. cit., p.107

${ }^{83}$ OLSON, 2001. p.1999.

${ }^{84}$ BETTENSON, 2011. p.63.

${ }^{85}$ NOLL, 2000. p.63.
}

Revista Pax Domini | Faculdade Boas Novas | v. 2 | p. 122 - 145 | mar. 2017 
foram se apropriando das decisões de Nicéia, não só em sentido negativo, associando-se em sentido á sua condenação do arianismo, mas também em sentido positivo, repensando o conteúdo do seu símbolo de fé e reconhecendo-o como tradição, ou seja, como expressão dogmática vinculativa e, de certo modo, definitiva. ${ }^{86}$

A trajetória de partida do concilio de Niceia até a chegada do concílio de Constantinopla, foi histórica e teologicamente muito longa. Pois foram os ataques sofridos pelo credo Niceno, o arianismo se estabeleceu em vantagem por longo tempo, tendo o apoio de muitos imperadores. Em consequência do poder imperial Atanásio foi posto em exílio por cinco vezes, e a cada retorno seu, deparava-se com um imperador diferente o que dificultava qualquer tentativa de aproximação.

Mas todos os obstáculos históricos foram impelidos a partir do governo de Teodósio que revigorou a causa Nicena, culminando na convocação do concílio de Constantinopla, proclamando definitivamente a doutrina da Trindade.

\section{COSIDERAÇÕES FINAIS}

Após essa longa trajetória histórica e teológica, fica notável que o concílio de Niceia e de Constantinopla foram essências para formulação de um dos dogmas fundamentais para o cristianismo, o dogma trinitário. Afinal, nenhum dogma ou doutrina do cristianismo surgiu do nada.

Para que fique claro que a Trindade foi formulada como dogma e não como uma simples doutrina, precisa-se compreender o seguinte: todo dogma é uma doutrina, mas nem toda doutrina é um dogma. Isso por que dogma é uma doutrina dotada de devida autoridade, sendo uma atividade própria da igreja, emergido de frequentes controvérsias teológicas. Tal como Roger Olson muito bem diferencia dogma de doutrina para aplicar o pressuposto do estudo da história da teologia afirmando que "as crenças cristãs, as consideradas verdadeiras, não tem o mesmo grau de importância". ${ }^{87}$ Nesse sentido os dogmas estão numa categoria superior às doutrinas, pois são crenças que delas dependem toda existência e essência da fé cristã, tais como a Encarnação, a Ressurreição, e aqui em destaque nesse trabalho a Trindade.

\footnotetext{
${ }^{86}$ ALBERICO, 2011. p.46.

87 OLSON, 2001, p.17.
}

Revista Pax Domini | Faculdade Boas Novas | v. 2 | p. 122 - 145 | mar. 2017 
Vale também fazer menção aos protagonistas do dogma Trinitário que são: Tertuliano, Orígenes, Atanásio, e os três pais capadócios (Basílio de Cesareia, Gregório de Nissa e Gregório de Nazianzo). Sendo estes responsáveis por levar a fórmula acerca do modo de entender a relação entre o Pai, o Filho e o Espirito Santo, o homoousios (a mesma substância).

A importância de se estudar os dogmas e as doutrinas do cristianismo é valoravel por conceder o poder de não transformar o cristianismo numa religião mitológica. E sem o estudo sistemático e Histórico deste tema, é impossível discorrelo enfaticamente e nem convencer alguém sobre sua veracidade, já que não consta na Bíblia sagrada os termos Trindade, Triunidade e Trinitário. Por isso este artigo fundamenta-se em esclarecer o leitor mostrando um panorama concernente do processo Histórico da Trindade no concilio de Niceia até o de Constantinopla, onde o importante não é só conhecer as doutrinas, mas também os pensamentos divergentes. Pois a formulação do dogma Trinitário só foi possível, a partir dos pensamentos formuladas pelos arianos, que está ligado com a História da igreja.

Ainda que muitos cristãos da atualidade entendam ou conheçam pouco sobre a formulação do dogma trinitário, isto não os impedem de incluir na base do culto litúrgico, a expressão de saudação "A graça de nosso Senhor Jesus Cristo, o amor de Deus e a comunhão do Espírito Santo estejam com todos vós". Tal expressão, hoje tão simples de se articular, muito traz em sua história o fôlego daqueles que bravamente defenderam a fé em um Deus sendo três.

\section{REFERÊNCIAS}

ALBERICO, Giuseppe. História dos Concílios ecumênicos. $4^{a}$ edição. São Paulo: Paulus, 2011.

BASTOS, Rogério Lustosa. Ciências humanas e complexidades: projetos, métodos e técnicas de pesquisa: o caos, a nova ciência. $2^{\underline{a}}$ edição. Rio de Janeiro: E-papers, 2009.

BETTENSON, Henry. Documentos da Igreja Cristã. $5^{\underline{a}}$ edição. São Paulo: ASTE, 2011.

CAMPENHAUSEN, Hans von. Os pais da Igreja. Rio de Janeiro: CPAD, 2013.

Revista Pax Domini | Faculdade Boas Novas | v. 2 | p. 122 - 145 | mar. 2017 
CESARÉIA, Eusébio de. História eclesiástica. Rio de Janeiro: CPAD, 2011. GONZÁLEZ, Carlos Ignácio. Ele é a nossa a salvação. São Paulo: Edições Loyola, 1992.

GONZÁLEZ, Justo L. História ilustrada do cristianismo: a era dos mártires até a era dos sonhos frustrados. 2a edição. São Paulo: Vida Nova, 2011.

HINSON, E. Gleann., SLEPLERSKI, Paulo. Vozes do cristianismo primitivo: o cristianismo como movimento que celebra sua unidade na diversidade, feito por indivíduos comuns, rumo à institucionalização. São Paulo: Arte Editorial, 2010.

HORTON, Stanley M. [et. al...]. Teologia Sistemática. Rio de Janeiro: CPAD, 1996. KELLY, J. N. D. Patrística origem e desenvolvimento das doutrinas centrais da fé cristã. São Paulo: Vida Nova, 1994.

LORENZEN, Lynne Faber. Introdução à Trindade. São Paulo: Paulos, 2002. MATOS, Alderi Souza de. Fundamentos da teologia. São Paulo: Mundo Cristão, 2008.

MORESCHINI, Cláudio., NORELLI, Eurico. História da Literatura Cristã Antiga Grega e Latina: II - do Concílio de Nicéia ao início da Idade Média [TOMO 1]. São Paulo: Edições Loyola, 2000.

NOLL, Mark A. Momentos decisivos na História do Cristianismo. São Paulo: Editora Cultura Cristã, 2000.

OLSON, Roger. História da Teologia Cristã. São Paulo: Editora Vida, 2001.

PADOVESE, Luigi. Introdução à Teologia Patrística. 2a edição. São Paulo: Edições Loyola, 2004.

PELIKAN, Jaroslov. A tradição cristã - uma história do desenvolvimento da doutrina. São Paulo: Shedd Publicações, 2014.

SHELLEY, Bruce L. História do cristianismo de todos: uma narrativa do desenvolvimento da Igreja Cristã através dos séculos. São Paulo: Shedd Publicações, 2004.

SOUZA, Alex Amorim de. 0 segundo Deus. Porto Alegre: Redes Editora, 2008. WALKER, Wiliston. História da igreja cristã. $3^{a}$ edição. São Paulo: ASTE, 2006.

Revista Pax Domini | Faculdade Boas Novas | v. 2 | p. 122 - 145 | mar. 2017 